\title{
Six cases of poisoning after a parenteral organic mercurial compound (Merthiolate)
}

\author{
J. H. M. Axton \\ M.B., M.R.C.P.(Lond. \& Glas.), D.C.H. \\ Department of Paediatrics and Child Health, University of Rhodesia, Salisbury
}

\begin{abstract}
Summary
The case histories of four children and two adults who were accidentally given toxic amounts of Merthiolate are recorded. The possible modes of action of Merthiolate in causing symptoms are discussed.

Five out of the six patients died, and necropsy showed extensive renal tubular necrosis in each case, and in two, evidence of diffuse intravascular coagulation.
\end{abstract}

Merthiolate (Thimerosal, Thiomersal) is an organomercurial compound widely used as an antiseptic agent. Its main application in medicine has been as a skin antiseptic, and it has also been incorporated as a preservative in attenuated polio and influenza virus preparations. Similarly, vials of antibiotic preparations may contain Merthiolate as a bactericidal agent to allow such vials to be used for several doses.

Toxic effects in man have been confined mainly to skin reactions, which on occasions may be severe (Epstein, 1963). Intravenous Merthiolate has been used in the treatment of subacute bacterial endocarditis with no apparent ill-effects (Powell \& Jameson, 1931). However, the doses were very small.

The following case histories record the clinical details of six patients who were accidentally given large amounts of Merthiolate, which was added as a preservative to a preparation of chloramphenicol for intramuscular use.

\section{Case report no. 1}

An African boy aged 7 years was admitted with a history of headache and fever for $24 \mathrm{hr}$, and one convulsion $12 \mathrm{hr}$ before admission. There was no evidence of meningitis and his cerebrospinal fluid was crystal clear. Diarrhoea developed soon after admission and clinically an acute shigella or salmonella infection was diagnosed. Intramuscular chloramphenicol was started, $500 \mathrm{mg}$ 6-hourly. His clinical condition improved rapidly, but 4 days after admission his right buttock was noted to be swollen and very tender. At the same time his temperature began to rise. Intramuscular chloramphenicol was stopped and treatment continued orally. Ten days after admission the skin over his right buttock appeared necrotic and a similar area appeared on the anterior aspect of the left thigh-both areas where intramuscular chloramphenicol had been given. His general condition remained static for a week and then started to deteriorate rapidly. After full investigation for a pyrexia of unknown origin, treatment with cloxacillin and colomycin was started. His haemoglobin had fallen to $3.9 \mathrm{~g}$, having been $11.4 \mathrm{~g}$ on admission. The reticulocyte count was $7 \cdot 5 \%$. Blood urea at this stage was $132 \mathrm{mg} / 100 \mathrm{ml}$ and the urine showed a large amount of glucose and albumin.

Nineteen days after admission he became very restless, and his speech was slurred. He became incontinent of urine and faeces and a left hemiparesis developed. He quickly lapsed into coma, with a rising blood urea and increasing acidosis, and died on the twenty-first day after admission (Fig. 1).

TABLE 1.

\begin{tabular}{lcccc}
\hline & $\begin{array}{c}\text { Weight } \\
(\mathrm{kg})\end{array}$ & $\begin{array}{c}\text { Chloramphenicol } \\
(\mathrm{g})\end{array}$ & $\begin{array}{c}\text { Merthiolate } \\
(\mathrm{g})\end{array}$ & $\begin{array}{c}\text { Mercury } \\
(\mathrm{g})\end{array}$ \\
\hline Case 1 & 17 & 11.0 & $5 \cdot 5$ & $1 \cdot 8$ \\
Case 2 & 16 & 6.0 & 3.0 & 1.0 \\
Case 3 & 5 & 0.9 & $0 \cdot 45$ & $0 \cdot 15$ \\
Case 4 & 14 & 2.0 & 1.0 & $0 \cdot 3$ \\
Case 5 & 90 & 24.0 & 12.0 & 4.0 \\
Case 6 & 50 & 33.0 & 16.5 & $5 \cdot 5$ \\
\hline
\end{tabular}

Molecular weight Merthiolate, 404; atomic weight mercury, 136.

\section{Necropsy (performed $2 \mathrm{hr}$ after death)}

The body showed extreme wasting. There was a $10 \mathrm{~cm}$ ulcer covered by a black eschar over the right buttock. The edge was undermined and indurated and the underlying muscles were brown and necrotic. There was no free pus and the changes extended almost to the pelvic bone. A $5 \mathrm{~cm}$ abscess containing thin brown material was found in the left thigh. Muscle necrosis in this area was also extensive.

Areas of apparent consolidation were found in both lungs and the spleen was moderately enlarged and congested. The only other significant macroscopic finding was the appearance of the kidneys which were enlarged and soft with pale cortices and injected medullae.

On histological examination antemortem thrombi were found in small vessels of the meninges, lung and 
in the medulla of one kidney. There were areas of early infarction of the lung and recent petechial haemorrhages in the brain. A section from the depth of the buttock abscess revealed necrosis of muscle and fat; culture of the abscess fluid and muscle was sterile. Both kidneys showed evidence of widespread degeneration and necrosis of the tubules. There was marked ballooning of proximal tubular cells, flattening of distal tubular epithelium and pigment casts in medullary tubules. Haematopoiesis was seen in vasa recta and lymphocytic aggregates were found in the interstitium round many renal corpuscles (as in Cases 2 and 4). Analysis of tissue mercury content: Kidney, $5 \mathrm{mg} / 100 \mathrm{~g}$; liver, $15 \cdot 1 \mathrm{mg} / 100 \mathrm{~g}$; buttock ulcer, $66 \mathrm{mg} / 100 \mathrm{~g}$; control calf muscle, $0.8 \mathrm{mg} / 100 \mathrm{~g}$.

\section{Case report no. 2}

An African child aged 7 years was admitted with a history of cough, abdominal pain and distension of the abdomen for 2 weeks. At laparotomy, pus was found in the peritoneal cavity coming from a perforated abscess in relation to the liver. This was drained, and intravenous fluids, nasogastric suction and intramuscular chloramphenicol were started postoperatively. He improved slowly, but 7 days later developed a high swinging fever and extremely pain- ful legs. Induration was noticed over the anterior aspects of both thighs, where the intramuscular injections had keen given. By the next day, these areas had become black and necrotic, and extended over an area of approximately $12 \times 6 \mathrm{~cm}$ on each thigh. Profuse watery diarrhoea developed 19 days after admission and 4 days later the child was noticed to be jaundiced. On the same day he tecame excitable, developed hallucinations and soon after lapsed into coma. He survived for a further 16 days, becoming steadily more jaundiced and uraemic up to the time of his death (6 November 1969-see Fig. 1). The correct diagnosis became known the day after the child became unconscious. Supportive treatment with i.v. fluids, nasogastric feeding, physiotherapy and antibiotics as necessary were given. British antilewisite (Dimercaprol) was given intramuscularly starting with $50 \mathrm{mg}$ 6-hourly for $24 \mathrm{hr}$, and continuing until death 15 days later, with $25 \mathrm{mg}$ twice daily.

\section{Investigations}

Haemoglobin on admission was $12.6 \mathrm{~g} / 100 \mathrm{ml}$; seven days later $7.4 \mathrm{~g} / 100 \mathrm{ml}$ with a reticulocyte count of $9 \%$. Despite transfusion with blood the haemoglobin level fell rapidly again over the next 10 days to $6 \cdot 1 \mathrm{~g} / 100 \mathrm{ml}$. when he was transfused once more. The blood film showed numerous target cells.

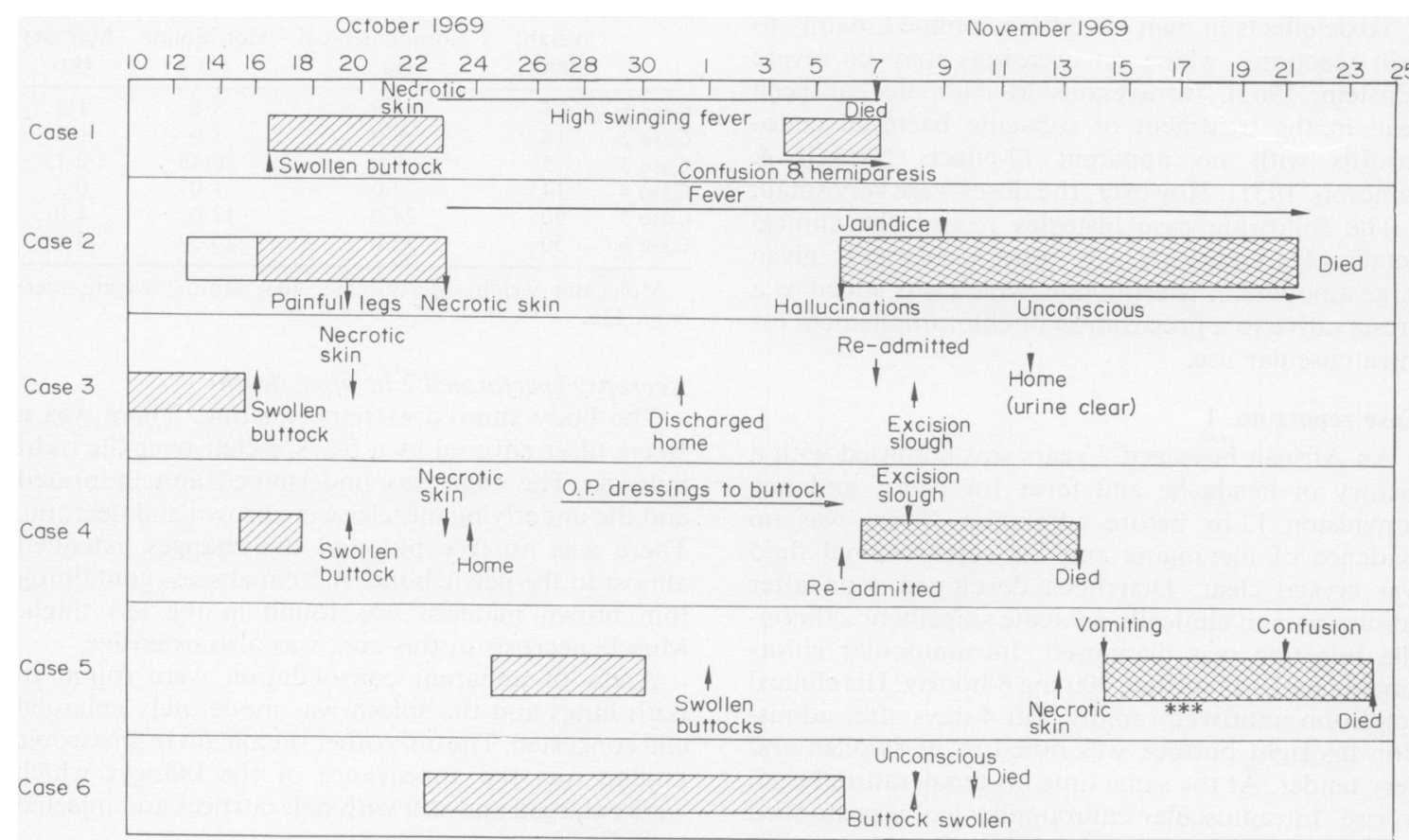

FIG. 1. Sequence of the illnesses of the six patients. Open areas, oral chloramphenicol; diagonally hatched areas, i.m. chloramphenicol; cross-hatched areas, glycosuria and albuminuria. Case 5,***, ataxia, slurred speech, mental deterioration. 
His urine, which was clear on admission, showed gross albuminuria and glycosuria coinciding with his clinical deterioration and lasting until his death. The daily volume of urine produced remained satisfactory and at no time was there any undue diuresis. However, the specific gravity remained low at 1.006 and he developed an increasingly high blood urea, which reached $260 \mathrm{mg} / 100 \mathrm{ml}$ before death. The total bilirubin level just before death reached $34 \mathrm{mg} / 100$ $\mathrm{ml}, 24 \mathrm{mg} / 100 \mathrm{ml}$ being unconjugated. Serum electrolytes throughout his illness remained satisfactory except for hypokalaemia which persisted despite potassium supplements.

\section{Necropsy (4 hr after death)}

Apart from the necrotic areas on the thighs, the abnormalities were confined to the histological examination. The kidneys showed fairly extensive focal necrosis of the proximal tubules, with evidence of regeneration. Granular and hyaline casts were present in many collecting tubules and there was some round cell infiltration close to the renal corpuscles. Bilharzia ova were found in the walls of the ureters with negligible tissue reaction.

The liver architecture was normal and necrosis was not seen. There was some cholestasis with bile in the canaliculi. Kuppfer cells were present, and some hepatocytes, the nuclei of which tended to be large and prominently nucleolated.

Oedema, with focal pneumonitis and bronchiolitis was present in the lungs. Analysis of the tissue mercury content showed: kidneys, $5.6 \mathrm{mg} / 100 \mathrm{~g}$; liver, $19 \cdot 9 \mathrm{mg} / 100 \mathrm{~g}$; muscle from calf, $5 \cdot 4 \mathrm{mg} / 100 \mathrm{~g}$.

\section{Case report no. 3}

A 6-week-old African female infant was admitted with pneumonia, which responded to treatment. Acidosis and severe hyperelectrolytaemia with fits developed, in association with diarrhoea, 5 days after admission (sodium greater than $170 \mathrm{mEq} / \mathrm{l}$, chloride $157 \mathrm{mEq} / \mathrm{l}$, potassium greater than $10 \mathrm{mEq} / \mathrm{l}$, bicarbonate $5.8 \mathrm{mEq} / 1$, blood urea $180 \mathrm{mg} / 100 \mathrm{ml}$ ). Intravenous fluids with sodium bicarbonate were given, and intramuscular chloramphenicol $50 \mathrm{mg}$ three times a day was started.

Five days after the first intramuscular injection of chloramphenicol, the right buttock was noted to be swollen. At that time it was thought to be due to intramuscular paraldehyde which was given to control the fits. A few days later an area over the buttock became necrotic. As the child was well, and the diagnosis at that time unknown, she was discharged to attend the out-patient department for daily dressings to the buttock.

At home the child did well, but when it was realized that Merthiolate had probably caused the necrosis, she was re-admitted. Electrolytes and liver function tests were normal. The urine showed a trace of albumin only. The haemoglobin, $10.3 \mathrm{~g}$ on the first admission, had fallen to $6.5 \mathrm{~g}$ and a small transfusion of blood was given. As it was thought that a good deal of Merthiolate could still be present in the buttock, a wide excision of necrotic tissue under general anaesthetic was performed (Mr R. Strover). The infant withstood this well and was discharged 5 days later. The cavity in the buttock healed well and during follow-up, which lasted 2 months, no abnormal physical signs were found on examination, and no albumin or glucose was found in the urine. British anti-lewisite was not given.

She was the first of the four children to be admitted and at the time of admission the preparation of chloramphenicol in use originated from a different source from that which became available a few days later. It is possible that only two or three injections of contaminated chloramphenicol were given, this accounting for her survival.

Analysis of the excised area of the right buttock showed a mercury content of $1.3 \mathrm{mg} / 100 \mathrm{~g}$ of tissue.

\section{Case report no. 4}

A well-fed, 2-year-old African boy was admitted with a history and signs suggesting meningitis. After lumbar puncture, treatment with i.m. penicillin, chloramphenicol and sulphadizaine was started. Meningococci were grown from the CSF and i.m. chloramphenicol was stopped, after only five injections. The child was discharged well, apart from an area of necrosis over the buttock, 10 days after admission. When it was known that Merthiolate was present in the injections of chloramphenicol, the child was re-admitted, 21 days after his previous admission and 20 days after his last injection of chloramphenicol.

On admission the child was well, but had signs of left-sided pneumonia. The urine showed large amounts of albumin and glucose. Electrolytes and liver function tests were normal. Haemoglobin was $9.5 \mathrm{~g} / 100 \mathrm{ml}$. The necrotic area on the left butlock was excised the day after admission and the child remained well for the next 5 days. On the sixth day he suddenly became extremely ill, with tachypnoea and a tachycardia of $260 / \mathrm{min}$. He became very drowsy and twitching of the arms and legs was noticed. He died within an hour.

British anti-lewisite (Dimercaprol) was given from the time of re-admission, $50 \mathrm{mg}$ i.m. 8-hourly for 2 days, followed by $25 \mathrm{mg}$ twice daily until the day of death.

\section{Necropsy}

Macroscopically no abnormality was found. On microscopy, the kidneys showed patchy lymphocytic periglomerular infiltration. There was proliferation 
of some tubular cells and degenerate cells present in the lumen of others. The lungs showed marked congestion and collapse. The liver and heart were normal. Tissue mercury: kidney, $5.6 \mathrm{mg} / 100 \mathrm{~g}$; liver. $6.6 \mathrm{mg} / 100 \mathrm{~g}$; excised left buttock, $9 \cdot 6 \mathrm{mg} / 100 \mathrm{~g}$.

\section{Case report no. 5}

An African woman, aged 29 years, was admitted with a history of abdominal pain, dysuria and fever for a week. A clinical diagnosis of pelvic sepsis after abortion was made, and she was treated with intravenous fluids, nasogastric suction and intramuscular chloramphenicol $500 \mathrm{mg}$ 6-hourly. Colpotomy the next day revealed pus, which grew Escherichia coli. Painful swollen buttocks were first noticed 9 days after admission. Two weeks later her temperature rose and she started to vomit. Her gait became unsteady, her speech slurred and mental deterioration, as evidenced by confusion, restlessness and depression, started at this time. She died 8 days after the onset of the mental symptoms, a month after the first injection of chloramphenicol.

Intramuscular British anti-lewisite (Dimercaprol) $100 \mathrm{mg}$ three times a day was given for the last 16 days of life and excision of the injection sites on both buttocks was performed 6 days before death. Throughout the period of admission her urinary output remained good, but albuminuria coincided with her clinical deterioration (see Fig. 1).

\section{Necropsy}

Abnormalities were confined to the microscopic examination of the kidneys. These showed patchy proximal tubular necrosis, with evidence of epithelial regeneration. Focal interstitial and periglomerular lymphocytic infiltration were also present.

Tissue mercury: kidney, $19.4 \mathrm{mg} / 100 \mathrm{~g}$; liver, $16 \cdot 1 \mathrm{mg} / 100 \mathrm{~g}$; brain, $2 \cdot 0 \mathrm{mg} / 100 \mathrm{~g}$.

\section{Case report no. 6}

An African woman aged 39 years was admitted with a history of headache and blurred vision for 2 weeks. The cerebrospinal fluid findings suggested either a partially treated purulent meningitis or tuberculous meningitis. Treatment with penicillin, sulphadiazine and chloramphenicol was started and later, streptomycin, PAS and INAH were added. Two days after admission she became delirious and 13 days later suddenly lost consciousness. She died the next day.

\section{Necropsy}

The findings were consistent with miliary tuberculosis. Microscopically, the kidneys showed moderately severe tubular necrosis with some regeneration. Antemortem thrombi was seen in a large renal vein.
In the brain there was evidence of chronic meningitis with lymphocyte and plasma cell infiltration. Petechial haemorrhages and infarction were present in the underlying brain, associated with antemortem thrombi in some small arterioles.

Tissue mercury: right buttock, $27 \mathrm{mg} / 100 \mathrm{~g}$; left buttock, $7 \cdot 1 \mathrm{mg} / 100 \mathrm{~g}$.

\section{Discussion}

Figure 1 shows the time sequence of the illnesses of the six patients.

That there was something wrong with the chloramphenicol injections was first suspected on 23 October 1969 , following the appearance of skin necrosis over the injection sites in the four children, and the drug was withdrawn from the paediatric wards. Preliminary investigation of the vials used, for $\mathrm{pH}$, concentration of chloramphenicol, and bacteriology, revealed no abnormality. Heavy metal contamination was not considered at this stage.

Case 1 was the first to die (6 November 1969) and on the morning of his death, the combination of albuminuria and glycosuria with mental symptoms suggested poisoning, possibly by a heavy metal. This suspicion was supported by the necropsy findings later in the day (large swollen kidneys).

Reference was again made to the local manufacturers of the chloramphenicol and it was discovered that $0.51 \mathrm{~kg}$ of Merthiolate had been used in the preparation of $10001 \mathrm{~g}$ vials of chloramphenicol. The correct amount should have been $0.51 \mathrm{~g}$. The amount of Merthiolate in each vial was 1000 times too much.

The $\mathbf{L D}_{50}$ for Merthiolate in man is unknown. However, these six patients received between two and six times the $\mathrm{LD}_{50}$ for rats $\left(\mathrm{LD}_{50} 60 \mathrm{mg} / \mathrm{kg}\right.$; Miller, Klavano \& Csonka, 1960).

Table 1 shows the total dose of chloramphenicol given intramuscularly, the total dose of Merthiolate and the total weight of mercury given.

Cases 5 and 6 were discovered when a systematic search was made throughout the hospital for other patients being treated with chloramphenicol by intramuscular injection.

The metabolism and toxic effects of phenyl mercuric compounds, of which Merthiolate is one, have been extensively investigated in animals (Powell \& Jameson, 1931; Miller et al., 1960; Ladd Goldwater \& Jacobs, 1964; Friberg, Odeblad \& Forssman, 1957). After subcutaneous, intravenous or intramuscular injections of phenyl mercuric acetate or nitrate, the unchanged compounds are excreted in the urine or can be recovered from the body tissue. After 4 days, no unchanged compound can be found in the tissues or urine, and it is assumed that break down to simpler compounds is complete. The breakdown products are unknown, but might include 
inorganic mercury or an ethyl mercury compound (Lyle, 1969).

Using labelled phenyl mercuric acetate in animals, Friberg et al. (1957) found that concentration of mercury occurred mainly in the kidneys and liver, and mercury remained in high concentration in these organs. Comparatively small amounts were found in the brain.

The pathological lesions produced in animals by phenyl mercuric compounds are essentially the same as those produced by subacute or chronic mercury poisoning (Powell \& Jameson, 1931; Miller et al., 1960). The kidneys are the main organs affected, being usually enlarged and pale. Microscopically the glomeruli appear normal, but changes in the proximal tubules are marked, ranging from cloudy swelling to necrosis with lipid deposition. The tubules may contain much cellular debris and amorphous casts.

In man, the effects of phenyl mercuric compounds have not been extensively investigated. Epstein (1963) reports on five cases of allergy to Merthiolate given subcutaneously (the Merthiolate was present in diluting fluid used in skin sensitivity tests for dermatitis). Powell \& Jameson (1931) report on the use by Smithburn of i.v. Merthiolate in treating twenty-two cases of subacute bacterial endocarditis. The maximum single dose was $50 \mathrm{ml}$ of a $1 \%$ solution and the maximum total dose to any one patient was $180 \mathrm{ml}$. No adverse effects were noted except in one patient where part of the injection was given subcutaneously instead of intravenously by mistake. This produced a large infiltrated slough of the anterior cubital area. However, Kinsella (1941) also reporting on the use of Merthiolate in four cases of subacute bacterial endocarditis found evidence of mercury poisoning in one at necropsy.

Most of the blood plasma produced for use in World War II was preserved with Merthiolate up to a concentration of $0 \cdot 1 \mathrm{~g} / \mathrm{l}$ and no adverse effects were reported (Bader, 1969). Ansell \& Cadwallader (1964) report, however, that a concentration of Merthiolate of $10 \mathrm{~g} / 1$ will haemolyse human red cells. It is of significance that in both Case 1 and 2 there was a blood picture suggesting acute haemolysis and this could have resulted from the effects of unchanged Merthiolate in the bloodstream and tissues. However, the generalized intravascular thrombosis seen in Case 1 and Case 6, together with the haemolytic anaemia, suggest that there may have been a diffuse intravascular coagulation defect similar to the syndrome of micro-angiopathic haemolytic anaemia.

The symptoms and clinical course of the six patients suggests subacute mercury poisoning. In acute poisoning, death is usually rapid, as a result of cellular enzyme poisoning by the mercuric ion. In chronic poisoning, where small amounts of mercury are ingested over a long period, as in Minamata disease, symptoms are mainly neurological. In intermediate forms of poisoning the kidneys are usually affected, as in the cases reported here, but in none of these cases could the renal damage have been the immediate cause of death.

Three patients were given maximal doses of BAL and none of them survived. This suggests that the mercury compounds produced by the degradation of Merthiolate were in a non-chelatable form. Unfortunately, the effect of BAL on mercury excretion in the urine was not measured, so this remains hypothetical. Apart from excision of the injection sites, the only other treatment which might have influenced the clinical course was haemodialysis or peritoneal dialysis. Neither was attempted in any of these cases.

\section{Addendum}

The error in manufacture of the chloramphenicol ampoules arose over mistyping kilogram for gram.

\section{Acknowledgments}

My thanks are due to Dr T. G. Ashworth and Dr M. Ross for the necropsy reports, to Mr N. G. Shirley (Government Analyst) for the tissue mercury estimations, and to $\mathrm{Dr}$ H. McC. Giles, Professor R. Philpott and Dr J. Forbes for permission to report on cases in their care. Dr J. Bader and Dr W. H. Lyle gave valuable information regarding the metabolism of Merthiolate and possible methods of treating the cases.

The Secretary for Health (Rhodesia) gave permission for publication.

\section{References}

Ansell, H.C. \& Cadwallader, D.E. (1964) Haemolysis of erythrocytes by anti-bacterial preservatives. Jourral of Pharmaceutical Science, 53, 169.

BADER, J. (1969) Personal communication.

EPSTEIN, S. (1963) Sensitivity to Merthiolate: a cause of false delayed intra-dermal reactions. Journal of Allergy, 34, 225.

Friberg, L., Odeblad, E. \& Forssman, S. (1957) Distribution of two mercury compounds in rabbits after a single subcutaneous injection (mercuric chloride and phenyl mercuric acetate). Archives of Industrial Medicine, 16, 163.

KinSELLA, R.A. (1941) Chemotherapy of bacterial endocarditis. Annals of Internal Medicine, 15, 982.

Kurland, L.T., FARO, S.N. \& SEIDler, H. (1960) Minamata disease. World Neurology, 19, 370.

LADD, A.C., GoldWATER, L.J. \& JACOBS, M.B. (1964) Absorption and excretion of mercury in man. V. Toxicity of phenyl mercurials. Archives of Environmental Health, 9, 43.

LYLE, W.H. (1969) Personal communication.

Miller, V.L., Klavano, P.A. \& Csonka, E. (1960) Absorption, distribution and excretion of Phenyl mercuric acetate Toxicology and Applied Pharmacology, 2, 344.

Powell, H.M. \& JAMESON, W.A. (1931) Merthiolate as a germicide. American Journal of Hygiene, 13, 296. 